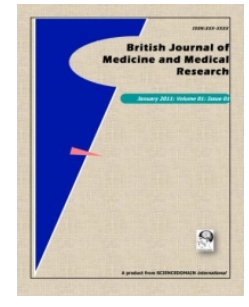

British Journal of Medicine \& Medical Research 4(8): 1691-1700, 2014

SCIENCEDOMAIN international

www.sciencedomain.org

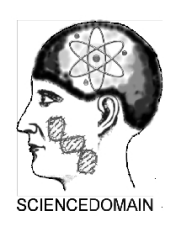

\title{
Porphyria Cutanea Tarda and HFE Gene Mutations in Argentina
}

\author{
Colombo Federico ${ }^{1,2}$, Martínez Javier ${ }^{1,2}$, Varela Laura ${ }^{1}$, Gerez Esther ${ }^{1}$, \\ Méndez Manuel ${ }^{1,3}$, Batlle Alcira ${ }^{1}$, V. Rossetti María ${ }^{1,2}$ \\ and E. Parera Victoria ${ }^{1,2^{\star}}$ \\ ${ }^{1}$ Centro de Investigaciones sobre Porfirinas y Porfirias, CIPYP, CONICET, Hospital de \\ Clinicas José de San Martín: Av Córdoba 2351--, Buenos Aires, Argentina. \\ ${ }^{2}$ Department of Biological Chemistry, Faculty of Exact and Natural-Sciences University of \\ Buenos Aires, Ciudad Universitaria. Pavilion II, 4th floor, Buenos Aires, Argentina. \\ ${ }^{3}$ Porphyrias Research Centre, University Hospital 12 de Octubre. Av. Córdoba s/n. Madrid, \\ Spain.
}

\section{Authors' contributions}

This work was carried out in collaboration among all authors. Author BA is Superior, authors VRM and EPV are Independent and author GE is Associate researcher respectively in the Career of Scientific Researcher at the Argentine National Research Council (CONICET), author VL is Associate Professional in the Research Assistant Career at CONICET, authors $M M$ and CF were Research Fellows from the CONICET, author MJ was Research Fellow at CIPYP. Authors CF and MJ carried out most of the genetic studies, performed the statistical analysis and prepared the Tables of the manuscript. They contributed equally to this publication. Authors GE and VL contributed with some genetic determinations. Author MM carried out the enzymatic determinations and part of the molecular studies.

$A B$ read and made the corrections of the manuscript. Author EPV was the responsible for the patient's diagnosis, wrote the first draft of the manuscript and managed the literature searches. Authors EPV and VRM designed the study, supervised the experiments and the analysis of the results. All authors read and approved the final manuscript.

Original Research Article

Received $1^{\text {st }}$ October 2013 Accepted $5^{\text {th }}$ December 2013 Published 27 $7^{\text {th }}$ December 2013

\section{ABSTRACT}

Aims: Porphyria Cutanea Tarda (PCT), the most common of porphyrias is triggered by several factors, including iron overload. Type I Hereditary Hemochromatosis is inherited as an autosomal recessive trait of the mutation p.C282Y or as a compound

*Corresponding author: Email: vparera14@hotmail.com, vicky@qb.fcen.uba.ar; 
heterozygous form p.C282Y/p.H63D in HFE gene.

Our aim was to study the frequency of HFE mutations in Argentinean PCT patients and in control subjects.

Place and Duration of Study: CIPYP, CONICET, Hospital de Clínicas José de San Martín: Av. Córdoba 2351, $1^{\circ}$ subsuelo, Buenos Aires, Argentina (1120). Between March 2008 and March 2010.

Methodology: We analyzed HFE mutations in 103 PCT patients (67 males, 36 females) and in 93 control subjects ( 63 males and 30 females). PCT patients were classified as familial, sporadic or Type III PCT measuring URO-D activity in red blood cells. HFE mutations were detected by amplification and automatic sequencing of exons 2 and 4 in the HFE gene. In some cases p.H63D and p.C282Y mutations were also detected by digestion with restriction enzymes (Mbo / for p.H63D and Rsa I for p.C282Y), followed by $3 \%$ polyacrilamide gel electrophoresis.

Results: In PCT group, 34.9\% carried mutation p.H63D (26.2\% heterozygous, $5.8 \%$ homozygous and $2.9 \%$ as p.C282Y/p.H63D) and $7.8 \%$ carried mutation p.C282Y $(2.9 \%$ in heterozygocity, $1.9 \%$ in homozygocity and $2.9 \%$ as p.C282Y/p.H63D). In the control group, $30.1 \%$ carried p.H63D ( $28 \%$ in heterozygous and $2.1 \%$ in homozygous), and $5.4 \%$ had p.C282Y in heterozygosity. There were no significant differences between sporadic and familial PCT and neither between PCT and control groups. Our findings are in agreement with the prevalence of the Mediterranean origin of our patients, where p.C282Y mutation is less common than p.H63D mutation.

Conclusion: We conclude that mutations in HFE gene do not play a relevant role in the triggering of PCT in our country.

Keywords: Porphyria Cutanea Tarda (PCT); sporadic PCT; familial PCT; Hereditary Hemochromatosis; p.C282Y mutation; p.H63D mutation.

\section{INTRODUCTION}

Porphyria Cutanea Tarda (PCT) is the most common porphyria clinically characterized by hyperpigmentation, skin photosensibility with blistering on sun exposed areas, skin fragility and hyperthricosis. The disease is due to subnormal activity of Uroporphyrinogen Decarboxylase (URO-D, EC 4.1.1.37). There are two main forms of PCT: Sporadic PCT (sPCT or Type I) and Familial PCT (f-PCT or Type II) [1], transmitted as a dominant trait with low penetrance. There is other form of PCT called Type III, where a familial history of PCT is observed, however subnormal URO-D activity is restricted to the liver [2]. Moreover, URO-D mutations in homozygosis or in compound heterozygosis cause a more severe form of hereditary PCT named Hepatoerythropoietic Porphyria (HEP) [3]. The clinical manifestation of PCT is frequently associated to the exposure to the well known precipitating agents, including polyhalogenated aromatic hydrocarbons such as hexachlorobenzene, alcohol abuse, estrogens ingestion, iron overload and infection with hepatitis $\mathrm{C}$ virus (HCV) and less frequently hepatitis B virus (HBV) [4]. All of these factors cause liver dysfunction, a common sign in PCT patients.

It is well known that mild to moderate hepatic iron overload plays a key role in the pathogenesis of PCT. Although it is now accepted that iron does not directly inhibit URO-D, it is required for its inactivation [5] and it participates in the generation of reactive oxygen species increasing oxidative stress, promoting the oxidative modification of porphyrinogens to porphyrins which are accumulated in liver [6]. 
The causes of iron overload appear to be heterogeneous. An impaired iron metabolism and so altered iron status may be secondary to exogenous factors such as alcohol [7], diet or other sources of iron excess [6]. In patients with chronic viral hepatitis (HBV and HCV) an increased deposition of iron in the liver is also observed [8,9]. PCT associated to infection with the human immunodeficiency virus (HIV) has also been reported [10-12]. However, the role of HIV in triggering PCT is not yet clear because in most PCT-HIV patients HCV infection and an alcohol and/or drug abuse history are also observed [4,13-15].

Hemochromatosis is the most common cause of primary iron overload. It has been shown that hereditary hemochromatosis $(\mathrm{HH})$ could also be associated with f-PCT and S-PCT outbreak. Mutations p.C282Y and p.H63D in the HFE gene have been found in both f-PCT and S-PCT, more commonly than in control populations [16-24]. However, differences between PCT and control subjects were not found in other populations [25-29].

$\mathrm{HH}$ is one of the most common inherited metabolic diseases in Caucasian populations [30]. The main cause of this disorder is the progressive overload of iron in several tissues and organs leading to a severe hepatic, pancreas and heart cellular damage, where the iron concentration is higher. At present there are 5 types of $\mathrm{HH}$, each one linked to a specific gene, and therefore, to a different protein involved in iron metabolism. In 1996, Feder et al [31], identified a candidate gene for $\mathrm{HH}$ in chromosome $6 p$ that codifies HFE protein, involved in iron absorption, detecting two mutations, p.C282Y and p.H63D, associated to $\mathrm{HH}$ type 1. Later, p.S65C mutation was implicated in a mild form of $\mathrm{HH}[32,33]$.

The p.C282Y mutation is more frequent in northern European populations while p.H63D is more frequent in Mediterranean populations. Because Italian and Spanish ascendants are very important in Argentina, the aim of this study was to examine the association between HFE mutations and the triggering of PCT in our country.

\section{MATERIALS AND METHODS}

\subsection{Patients and Controls}

We studied 103 PCT patients (67 males, 36 females) and 93 blood donors controls (63 males and 30 females). Informed consent was obtained from all patients and controls. To classify PCT patients in familial, sporadic or Type III PCT, URO-D activity was measured in red blood cells (RBC) (4) and mutations responsible of PCT were detected in all f-PCT patients [34-36]. In the two families with type III PCT, URO-D activity was within control values $(4.2 \pm 0.6 \mathrm{nmol}$ coproporphyrinogen $\mathrm{III} / \mathrm{h} / \mathrm{ml} \mathrm{RBC})$ and mutations were not found in the URO-D gene. All PCT patients included in the study had altered iron metabolism at diagnosis.

\subsection{Mutational Analysis}

Genomic DNA was extracted from EDTA-collected blood samples which were analysed for the common HFE mutations (p.H63D, p.S65C and p.C282Y) by Polymerase Chain Reaction (PCR) and automatic sequencing in an ABI prism 3730XL. PCR was performed using two sets of primers (Table 1) for amplification of exons 2 and 4 in the HFE gene and the purified products were sequenced employing the same primers used for PCR reactions. In some cases p.H63D and p.C282Y mutations were also detected by digestion with restriction enzymes (Mbolfor p. H63D and Rsalfor p. C282Y), followed by $3 \%$ polyacrilamide gel electrophoresis. This method was tested as a possible routine diagnostic tool for these 
mutations. Our results (data not shown) were in correspondence with those obtained by the sequencing method.

Table 1. Primers for amplification and sequencing reaction

\begin{tabular}{ll}
\hline Primer & $\mathbf{5}^{\prime} \mathbf{-} \mathbf{3}^{\prime}$ \\
\hline R1 & $5^{\prime}$-AAAGACAGGACTGCAACTCACCC- $3^{\prime}$ \\
R2 & $5^{\prime}$-AGCAAATTCCTTCCCTCTTCCC- $3^{\prime}$ \\
H1 & $5^{\prime}$-CCTCCTTTGGTGAAGGTGACACAT-3' \\
H2 & $5^{\prime}$ - AGATCACAATGAGGGGCTGATCCA-3' \\
J1 & $5^{\prime}$-TGGCAAGGGTAAACAGATCC- 3' \\
J2 & $5^{\prime}$-CTCAGGCACTCCTCTCAACC- 3' \\
\hline
\end{tabular}

The same primers were employed to amplify exon 2 (R1 and R2) for both sequencing reactions and RFLP analysis. However to amplify exon $4, \mathrm{H} 1 / \mathrm{H} 2$ and $\mathrm{J} 1 / \mathrm{J} 2$ primers were used for sequencing and RFLP analysis respectively.

\subsection{Statistical Analysis}

Data were analyzed using the Student's t-test and the Chi-square test to compare allelic and genotypes frequencies and estimate differences in proportions using Statistix 9 software. A $p<0.05$ was considered as significant .

\section{RESULTS}

A group of 103 Argentinean PCT patients was studied, along with a group of 93 control subjects (Table 2).

Table 2. Number of patients studied, type of PCT and age at manifestation

\begin{tabular}{|c|c|c|c|c|c|}
\hline & $\begin{array}{l}\text { Total PCT } \\
(n=103)\end{array}$ & $\begin{array}{l}\text { f-PCT } \\
(n=37)\end{array}$ & $\begin{array}{l}\text { s-PCT } \\
(n=64)\end{array}$ & $\begin{array}{l}\text { Type III PCT } \\
(n=2)\end{array}$ & $\begin{array}{l}\text { Controls } \\
(n=93)\end{array}$ \\
\hline Female & 36 & 14 & 21 & 1 & 30 \\
\hline Male & 67 & 23 & 43 & 1 & 63 \\
\hline Age & $43.85 \pm 14.56$ & $41.67 \pm 15.80$ & $47.24 \pm 11.06$ & $48 \pm 5.66$ & $42.68 \pm 15.50$ \\
\hline
\end{tabular}

The frequency of different genotypes in controls and PCT subjects is shown in Table 3 . It can be seen that in both groups of PCT patients, familial and sporadic, about $60 \%$ of them had no mutation and about $25 \%$ had only p.H63D mutation in the heterozygous state. These results were similar to control group frequencies. No significant differences $(p=0.10)$ were observed for other genotypes between both types of PCT and control values.

From the total group of 103 PCT subjects the presence of p.S65C mutation was found only in one s-PCT male patient in heterozygous form.

The two patients with Type III PCT did not carry any of the three mutations investigated.

Table 5 comparatively shows our results and those reported for other populations. 
Table 3. Genotype frequencies in PCT patients and controls

\begin{tabular}{|c|c|c|c|c|c|c|c|c|c|}
\hline p.C282Y & $-/-$ & $-/-$ & $-/-$ & $+/-$ & $+/-$ & $+/-$ & $+/+$ & $+/+$ & $+/+$ \\
\hline p.H63D & $-/-$ & $-/+$ & $+/+$ & $-/-$ & $-1+$ & $+/+$ & $-/-$ & $-1+$ & $+/+$ \\
\hline Total PCT $(n=103)$ & $62(60.2)$ & $27(26.2)$ & $6(5.8)$ & $3(2.9)$ & $3(2.9)$ & $0(0)$ & $2(1.9)$ & $0(0)$ & $0(0)$ \\
\hline f-PCT $(n=37)$ & 24 (64.9) & $9(24.3)$ & $1(2.7)$ & $1(2.7)$ & $2(5.4)$ & $0(0)$ & $0(0)$ & $0(0)$ & $0(0)$ \\
\hline$s-P C T(n=64)$ & $36(56.3)$ & $18(28.1)$ & $5(7.8)$ & $2(3.1)$ & $1(1.5)$ & $0(0)$ & $2(3.1)$ & $0(0)$ & $0(0)$ \\
\hline Type III PCT $(n=2)$ & $2(100)$ & $0(0)$ & $0(0)$ & $0(0)$ & $0(0)$ & $0(0)$ & $0(0)$ & $0(0)$ & $0(0)$ \\
\hline Controls $(n=93)$ & $60(64.5)$ & $26(28)$ & $2(2.1)$ & $5(5.4)$ & $0(0)$ & $0(0)$ & $0(0)$ & $0(0)$ & $0(0)$ \\
\hline
\end{tabular}

The same result was obtained for allelic frequencies of p.C282Y and p.H63D between PCT and control groups $(p=0,80)$ (Table 4).

Table 4. Allelic frequencies in PCT patients and controls.

\begin{tabular}{lllll}
\hline & p.C282Y & \multicolumn{3}{l}{ P.H63D } \\
\hline & $\mathbf{G}$ & $\mathbf{A}$ & $\mathbf{C}$ & $\mathbf{G}$ \\
\hline Controls $(\mathrm{n}=186)$ & $0.97(\mathrm{n}=181)$ & $0.03(\mathrm{n}=5)$ & $0.84(\mathrm{n}=156)$ & $0.16(\mathrm{n}=30)$ \\
PCT $(\mathrm{n}=206)$ & $0.99(\mathrm{n}=196)$ & $0.05(\mathrm{n}=10)$ & $0.79(\mathrm{n}=163)$ & $0.21(\mathrm{n}=43)$ \\
\hline \multicolumn{4}{c}{ Differences were not considered statiscally significant $(\mathrm{p}=0.80)$ by Statstix 9 software. }
\end{tabular}

\section{DISCUSSION}

Genotypes and allelic frequencies were similar for both types of PCT and control subjects, but p.H63D was the most frequent mutation in at least one allele $(42 / 103,40 \%)$ according with our Mediterranean origin, where this mutation is more frequent than p.C282Y $[18,37]$ in both, PCT and control groups. A lower frequency of these mutations was found in another control population from the province of Córdoba, Argentina, where $81.9 \%$ did not show any mutation [38]. This difference could be attributed to the larger number of subjects studied by Soria et al. [38]. Although the number of controls in our study is smaller than that analized by Soria et al. [38], it is higher than those included in studies from most of other populations (Table 5).

In Italy [16], as in our country, p.H63D was also more frequent than p.C282Y, but unlike our results there was a significant difference between PCT and control groups. González Hevilla et al. [39] also found, for Spanish population from Madrid, a higher frequency of p.H63D and a significant difference for homozygous p.C282Y and compound heterozygous p.C282Y/p.H63D in PCT subjects. On the contrary, Castiella et al [29] described no relevant role for these mutations in PCT development for a Spanish population from Guipúzcoa. For other populations a significant difference of p.C282Y and/or p.H63D in heterozygous or homozygous state and compound heterozygous p.C282Y/p.H63D, between PCT and control subjects, was found [21,24,26-28,40-44]. Hift et al. [27] reported that although p.C282Y and p.H63D mutations were important factors in PCT triggering in an European population studied, neither of them were found in African subjects. 
Table 5. Studies from different populations

\begin{tabular}{|c|c|c|c|c|c|c|c|}
\hline Reference & Country & PCT/Control n & p.H63D/wt \% & p.H63D/p.H63D \% & p.C282Y/wt \% & p.C282Y/p.C282Y \% & p.H63D/p.C282Y \% \\
\hline This study & Argentina & $103 / 93$ & $26.2 / 27.9$ & $5.8 / 2.2$ & $2.9 / 5.4$ & $1.9 / 0$ & $2.9 / 0$ \\
\hline Roberts et al, 1997 [40] & UK & $41 / 101$ & $22.0 / 22.0$ & $2.0 / 0.3$ & $19.0 / 0.6$ & $17.0 / 0.1$ & $0.7 / 0.4$ \\
\hline Stuart et al, 1998 [17] & Australia & 27 & 37.0 & 7.4 & $33.3 / 11.5$ & $11.1 / 0.7$ & - \\
\hline Sampietro et al, 1998 [18] & Italy & $68 / 128$ & $42.6 / 22.6$ & $7.3 / 1.5$ & $2.9 / 1.5$ & $0 / 0$ & $1.5 / 0$ \\
\hline Bulaj et al, 2000 [41] & USA & $87 / 56$ & $15.0 / 18.0$ & $7.0 / 2.0$ & $15.0 / 13.0$ & $19.0 / 0$ & $6.0 / 0$ \\
\hline Martinelli et al, 2000 [42] & Brazil & 23 & 21.7 & $30.4 / 31.1$ & 13.0 & 0 & 4.3 \\
\hline Tannapfel et al, 2001 [20] & Germany & $190 / 115$ & $43.0 / 10$ & $2.0 / 0$ & $28.0 / 3.0$ & $12.0 / 0$ & $9.0 / 0$ \\
\hline Skowron et al, 2001 [43] & France & 56 & 32.1 & 7.1 & 16.0 & 14.2 & 0 \\
\hline Hift et al, 2002 [27] & South Africa & $34 / 108$ & $38.2 / 14.8$ & $0 / 1.9$ & $17.6 / 21.3$ & $8.8 / 0.9$ & $0 / 0$ \\
\hline Stolzel et al, 2003 [44] & Germany & $62 / 115$ & $29.0 / 12.0$ & $0 / 0$ & $15.0 / 3.0$ & $5.0 / 0$ & $13.0 / 0$ \\
\hline $\begin{array}{l}\text { Gonzalez-Hevilla et al, } \\
2005 \text { [39] }\end{array}$ & $\begin{array}{l}\text { Spain } \\
\text { (Madrid) }\end{array}$ & $63 / 88$ & $29.4 / 25.6$ & $9.5 / 5.7$ & $3.2 / 3.4$ & $12.7 / 0$ & $7.9 / 0$ \\
\hline Frank et al, 2006 [28] & Germany & $51 / 54$ & $35.3 / 29.6$ & $3.9 / 3.7$ & $15.7 / 5.6$ & $7.8 / 0$ & $2 / 1.9$ \\
\hline Kratka et al, 2008 [22] & $\begin{array}{l}\text { Czech } \\
\text { Republic }\end{array}$ & $63 / 481$ & $41.3 / 26.6$ & $6.3 / 1.7$ & $23.8 / 6.9$ & $6.3 / 0$ & $7.9 / 1.9$ \\
\hline Castiella et al, 2008 [29] & $\begin{array}{l}\text { Spain } \\
\text { (Guipuzcoa) }\end{array}$ & $54 / 116$ & $38.9 / 38.8$ & 11.1 & 3.7 & 0 & 7.4 \\
\hline Cribier et al, 2009 [23] & France & $59 / 60$ & $23.7 / 18.6$ & $6.8 / 0$ & $16.9 / 8.5$ & $1.7 / 0$ & $6.8 / 0$ \\
\hline Aarsand et al, 2009 [24] & Norway & $243 / 204$ & $20.0 / 17.2$ & $5.8 / 1.5$ & $15.6 / 12.3$ & $6.6 / 0.5$ & $8.6 / 1.0$ \\
\hline
\end{tabular}




\section{CONCLUSION}

We therefore can conclude that these mutations do not play a relevant role in PCT development in our country. Similar results were previously found for Argentinean Hemochromatosis patients [45].

Although in our country ethanol ingestion, polyhalogenated aromatic hydrocarbons exposure and estrogens therapy are the major PCT triggering factors [35] it is true that most of the patients have iron metabolism alterations at PCT diagnosis. So, as this fact could not be explained by HFE mutations, we think that other genes involved in iron metabolism could be associated in the triggering of both PCT and HH [45]. Hepcidin, codified by HAMP gene, seems to be the master regulator of iron metabolism in humans. HAMP mutations are responsible of type $2 \mathrm{HH}$, which is a non HFE-hemochromatosis [46]. Taking this into account, we have already started with the molecular analysis of the HAMP gene.

\section{ACKNOWLEDGEMENTS}

We wish to thank to H. Muramatsu, M.D., Lic. L. Oliveri and Mrs. V. Castillo for their technical assistance with the patients. This work was supported by grants from the University of Buenos Aires - UBA (X-165 and X-195), and the Science and Technology Argentine Agency (07-0268).

\section{CONSENT}

Not applicable.

\section{ETHICAL APPROVAL}

All authors hereby declare that all experiments have been examined and approved by the appropriate ethics committee and have therefore been performed in accordance with the ethical standards laid down in the 1964 Declaration of Helsinki.

\section{COMPETING INTERESTS}

Authors have declared that no competing interests exist.

\section{REFERENCES}

1. De Verneuil $H$, Aitken $G$, Nordmann $Y$. Familial and sporadic porphyria cutanea: two different diseases. Hum Genet. 1978;44:145-151.

2. Alessandro D, Gandolfo L, Griso D, Macri A, Biolcati G, Topi GC. Familial porphyria cutanea tarda with normal erythrocytic urodecarboxylase: an exception to the rule? Dermatologica. 1989;178:206-208.

3. Piñol Aguadé A, Herrero C, Almeida J, Castells Mas A, Ferrando J, De Asprer J, et al. Porphyrie hépato-érythrocytaire: une nouvelle forme de porphyrie. Ann Dermatol Syphiligr [Paris]. 1975;102:129.

4. Méndez M, Rossetti MV, Batlle AM del C, Parera VE. The role of inherited and acquired factors in the development of porphyria cutanea tarda in the Argentinean population. J Am Acad Dermatol. 2005;52:417-424. 
5. Elder GH, Roberts AG. Uroporphyrinogen decarboxylase. J Bioenerg Biomemb. 1995;27:207-214.

6. Sampietro M, Fiorelli G, Fargion S. Iron overload in porphyria cutanea tarda. Haematologica. 1999;84:248-253.

7. Chapman RW, Morgan MY, Laulicht M, Hoffbrand AV, Sherlock S. Hepatic iron stores and markers of iron overload in alcoholics and patients with hemochromatosis. Dig Dis Sci. 1982;27:909-916.

8. Di Biscaglie AM, Axiotics CA, Hoofmagle JH, Bacon BR. Measurements of iron startus in patients withy chronic hepatitis. Gastroenterology. 1992;102:2108-13.

9. Piperno A, D'Albas R, Fragion S, Roffi L, Sampietro M, Parma S, et al. Liver iron concentration of chronic viral hepatitis: a study of 98 patients. Eur J Gastroenterol. 1995; 7:1203-1208.

10. Wissel PS, Sordillo P, Anderson KE, Sassa S, Savillo R, Kappas A. Porphyria cutanea tarda associated with the acquired immune deficiency syndrome. Am J Hematol. 1987;25:107-113.

11. Parera V, Méndez M, Melito V, Stella AM, Jaled M, Bermejo A et al. Acerca de diecisiete pacientes con virus de inmunodeficiencia humana que desarrollaron porfiria cutánea tardía. Rev Argent Dermatol. 1995;76:230-235.

12. McAlister F, McClean K, Hamilton P. Human Immunodeficiency Virus Infection and Porphyria Cutanea Tarda: Coexistence of Risk Factors or Causative Association? Clin Infec Dis. 1995;20:348-351.

13. Drobacheff C, Derancourt C, Van Landuyt H, Devred D, de Wazieres B, Cribier B, et al. Porphyria cutanea tarda associated with human immunodeficiency virus infection. Eur J Dermatol. 1998;8:492-496.

14. Oubiña J, Quarleri J, Sawicky M, Mathet V, Ruiz V, Schroeder T, et al. Hepatitis C virus and GBV-C/hepatitis G virus in Argentinean patients with Porphyria Cutanea Tarda. Intervirology. 2001;44:215-218

15. Melito V, Parera V, Rossetti MV, Batlle A. Manifestación de la Porfiria Cutánea Tardía en pacientes infectados con el virus de la inmunodeficiencia humana. Acta Bioquím Clín Latinoam. 2006;40:29-34.

16. Fargion S, Francazani AL, Romano R, Cappellini MD, Fare M, Mattioli M, et al. Genetic hemochromatosis in Italian patients with porphyria cutanea tarda: possible explanation for iron overload. J Hepatol. 1996;24:569-574.

17. Stuart K, Busfield F, Jazwinska E, Gibson P, Butterworth L, Cooksley W. et al. The C282Y mutation in the haemochromatosis gene (HFE) and hepatitis $C$ virus infection are independent cofactors for porphyria cutanea tarda in Australian patients. J Hepatol. 1998;28:404-409.

18. Sampietro M, Piperno A, Lupica L, Arosio C, Vergani A, Corbetta N, et al. High prevalence of the H63D HFE mutation in italian patients with Porphyria Cutanea Tarda. Hepatology. 1998;27:181-184.

19. Brady J, Jackson H, Roberts A, Morgan R, Whatley S, Rowlands G, et al. Coinheritance of mutations in the Uroporphyrinogen Decarboxylase and Hemochromatosis Genes Accelerates the Onset of Porphyria Cutanea Tarda. Invest Dermatol. 2000;115:868-874.

20. Tannapfel A, Stolzel U, Kostler E, Melz S, Richter M, Keim V. et al. C282Y and H63D mutation of the hemochromatosis gene in German porphyria cutanea tarda patients. Virchows Archive. 2001;439:1-5.

21. Cruz-Rojo J, Fontanellas A, Morán-Jiménez M, Navarro-Ordoñez S, Garcia-Bravo M, Mendez M, el al. Precipitating/ aggravating factors of porphyria cutanea tarda in Spanish patients. Cell Mol Biol. 2002;48:845-852. 
22. Kratka K, Dostalikova-Cimburova M, Michalikova H, Stransky J, Vranova J. et al. High prevalence of HFE gene mutations in patients with porphyria cutánea tarda in the Czech Republic. B. J. Dermatology. 2008;159:585-590.

23. Cribier B, Chiaverini C, Dali-Youcef N, Schmitt M, Grima M, Hirth C. et al. Porphyria Cutanea Tarda, Hepatitis C, Uroporphyrirogen Decarboxylase and mutations of HFE gene. Dermatology. 2009;218:15-21.

24. Aarsand A, Boman H, Sandberg S. Familial and Sporadic Porphyria Cutanea Tarda: Characterization and Diagnostic Strategies. Clinical Chemistry. 2009;55:793-803.

25. Furuyama K, Kondo M, Hirata K, Fujita H, Sassa S. Extremely rare association of HFE mutations with porphyria cutanea tarda in Japanese patients. Hepatology. 1999;30:1532-1533.

26. Ivanova A, Von Ahnsen N, Adjarov D, Krastev Z, Oellerich M, Wieland E. C282Y and H63D mutations in the HFE gene are not associated with porphyria cutanea tarda in Bulgarian. Hepatology. 1999;30:1531-1532.

27. Hift RJ, Corrigal AV, Hancock V, Kannemeyer J, Kirsch RE, Meissner PM. Porphyria cutanea tarda: The etiological importance of mutations in the HFE gene and viral infections is population-dependent. Cell Mol Biol. 2002;48:853-859.

28. Frank J, Poblete-Gutiérrez P, Weiskirchen R, Gressner O, Merk HF, Lammert F. Hemochromatosis Gene Sequence Deviations in German Patients with Porphyria Cutanea Tarda. Physiol Res. 2006;55:S75-S83.

29. Castiella A, Zapata E, de Juan M, Mugica F, Barrio J, Otazua P, et al. Porphyria cutanea tarda. An analysis of HFE gene mutations, hepatitis viruses, alcohol intake, and other risk factors in 54 patients from Guipúzcoa, Basque Country, Spain. Rev Esp Enferm Dig. 2008;100:774-778.

30. Beutler E, Gelbert T, West C, Lee P, Adams M, Blackstone R: Mutation analysis in Hereditary Hemochromatosis. Blood Cells Mol Dis 1996;22:187-194.

31. Feder J, Gnirke A, Thomas W, Tsuchihashi Z, Ruddy DA, Basava A, et al. A novel MHC class I - like gene is mutated in patients with Hereditary Hemochromatosis. Nat Genet. 1996;13:399-408.

32. Mura C, Raguenes O, Ferec C. HFE mutations analysis in 711 Hemochromatosis probands: Evidence for S65C implication in mild form of Hemochromatosis. Blood. 1999;93:2502-2505.

33. Pietrangelo A. Hereditary hemochromatosis A new look at an old disease. N Engl J Med. 2004;350:2383-2397.

34. Mendez M, Sorkin L, Rossetti MV, Astrin K, Batlle A, Parera VE, et al. Familial Porphyria Cutanea Tarda: Characterization of seven novel Uroporphyrinogen decarboxylase mutations and frequency of common Hemochromatosis alleles. A J Hum Gen. 1998;63:1363-1375.

35. Mendez M, Rossetti MV, De Siervi A, Batlle A, Parera VE. Mutations in Familial Porphyria Cutanea Tarda: two novel and two previously described for Hepatoerythropoietic Porphyria. Human Mutation Mutation in Brief. 2000;16:269-274

36. Mendez M, Rossetti, MV, Gómez-Abecia S, Morán-Jiménez MJ, Parera VE, Batlle A, et al. Molecular analysis of the UROD gene in 17 Argentinean patients with familial porphyria cutanea tarda: characterization of four novel mutations. Molecular Genetics and Metabolism. 2012; 105:629-633

37. Enríquez de Salamanca R, Morales P, Castro MJ, Rojo R, González M, Arnaiz-Villena $A$, et al. The most frequent allele linked to porphyria cutanea tarda in Mediterraneans is H63D. Hepatology. 1999;30: 819-820.

38. Soria NW, Cossy Isasi S, Chaig MR. Gerez de Burgos MS. Analysis of C282Y and H63D mutations of the hemochromatosis gene HFE in blood donors from Cordoba Argentina. Ann Hematol. 2009;88:77-79. 
39. Gonzalez-Hevilla M, De Salamanca R, Morales P, Martinez-Laso J, Fontanellas A, Castro MJ, et al. Human leukocyte antigen haplotypes and HFE mutations in Spanish hereditary hemochromatosis and sporadic porphyria cutanea tarda. J Gastroenterol Hepatol. 2005;20:456-462.

40. Roberts A, Whatley S, Morgan R, Worwood M, Elder G. Increased frequency of the haemochromatosis Cys282Tyr mutation in sporadic porphyria cutanea tarda. The lancet. 1997;349:321-323.

41. Bulaj Z, Phillips J, Ajioka R, Franklin M, Griffen L, Guinee D, et al. Hemochromatosis genes and other factors contributing to the pathogenesis of porphyria cutanea tarda. Blood. 2000;95:1565-71.

42. Martinelli A, Zago M, Roselino A, Filho A, Villanova M, Secaf M, et al. Porphyria Cutanea Tarda in Brazilian Patients: Association with Hemochromatosis C282Y Mutation and Hepatitis C Virus Infection. Am J Gastroenterol. 2000;95:3516-3521.

43. Skowron F, Bérand $F$, Grézard $P$, Wolf $F$, Morel $Y$, Perrot $H$. Role of the hemochromatosis gene (HFE) in porphyria cutanea tarda. A prospective study of 56 cases. Ann Dermatol Venereol. 2001;128:600-604.

44. Stolzel U, Kostler E, Schuppan D, Richter M, Wollina U, Doss MO. et al. Hemochromatosis (HFE) Gene Mutations and Response to Chloroquine in Porphyria Cutanea Tarda. Arch Dermatol. 2003;139:309-313.

45. Rossetti M, Méndez M, Afonso S, Gerez E, Batlle A, Muñoz A, et al. HFE gene mutations in patients with altered iron metabolism in Argentina. Cell Mol Biol. 2009;55:31-35.

46. Santos P, Dinardo C, Costa Pereira A. Non-HFE hemochromatosis. Rev Bras Hematol Hemoter. 2012;34:311-316.

(C) 2014 Federico et al.; This is an Open Access article distributed under the terms of the Creative Commons Attribution License (http://creativecommons.org/licenses/by/3.0), which permits unrestricted use, distribution, and reproduction in any medium, provided the original work is properly cited.

Peer-review history:

The peer review history for this paper can be accessed here: http://www.sciencedomain.org/review-history.php?iid=380\&id=12\&aid=2851 